Article

\title{
Do Political Connections Affect the Conservative Financial Reporting of Family Firms?
}

\author{
Hsin-Yi Chi ${ }^{1}{ }^{1 * \mathbb{D}}$, Tzu-Ching Weng ${ }^{2}$, Guang-Zheng Chen ${ }^{2}$ and Shu-Ping Chen ${ }^{3}$ \\ 1 Department of Accounting, National Chung Hsing University, No. 250, Kuokuang Rd., \\ Taichung City 402, Taiwan \\ 2 Department of Accounting, Feng Chia University, No. 100, Wenhwa Rd., Taichung City 407, Taiwan; \\ tcweng@fcu.edu.tw (T.-C.W.); gzchen@fcu.edu.tw (G.-Z.C.) \\ 3 Department of Business Administration, National Chung Hsing University, No. 250, Kuokuang Rd., \\ Taichung City 402, Taiwan; jsy6273@gmail.com \\ * Correspondence: hychi@dragon.nchu.edu.tw; Tel.: +88-642-284-0828 (ext. 676)
}

Received: 29 August 2019; Accepted: 30 September 2019; Published: 10 October 2019

check for updates

\begin{abstract}
This paper investigates the effect of political connections on the association between family firms and conservative financial reporting. While family firms have incentives to reduce agency and litigation-related costs by means of conservative reporting, firms with political connections tend to have opaque financial reporting, which enable them to engage in rent-seeking activities. Using data for Taiwanese listed firms between 1996 and 2012, the final sample observations were 13,877 firm-year observations from a population of 21,393 firm-year observations. We found that political connections weaken the positive relationship between family ownership and conservative financial reporting. This suggests that politically connected family firms make fewer demands for conservative financial reporting. This study contributes to the literature on how political connections affect the family owners' reporting incentives. Policy makers may consider political connections as an essential factor with respect to establishing governance practice in family firms.
\end{abstract}

Keywords: conservative financial reporting; corporate governance; family control; political connections

\section{Introduction}

This study examines how political connections affect the relation between family firms and accounting conservatism. In recent years, there has been a dramatic increase in research regarding firms controlled by the founding family. Family firms are considered as owner-managed enterprises with families that exercise managerial or considerable financial control [1,2]. The difference between family and nonfamily firms is salient because family firms have a specific ownership structure in which their founders or descendants usually own the largest shares, control the firm, and have a seat on the board [3]. Conservative financial reporting is defined as the imposition of stricter verification standards for recording good news as gains than for recording bad news as losses. Conservative financial reporting benefits the users of financial information by mitigating agency problems between managers and other stakeholders [4,5], facilitating the monitoring of contracts, and constraining managers' opportunistic payments to related parties and themselves.

Families tend to hold their ownership in the firm over a longer horizon. This tight control may allow family self-dealings to go unchallenged internally by other shareholders and perhaps make it easier to extract rent at the cost of minority shareholders [1,6-9]. To avoid short-term shareholder benefit undertaken by families, minority shareholders may require a higher degree of verification to recognize good news as gains rather than bad news as losses. Additionally, as family members have longer investment horizons and pay more attention to firm survival than other stakeholders, they care about 
the negative influence on survival and reputation [1]. Due to family survival and reputation concerns, family firms tend to avoid risky and illegal activities. Thus, by delaying recognition of economic gains and understating net assets, conservative financial reporting could restrain opportunistic payments to managers and other related parties of the firm and then mitigate the likelihood of investor litigation against family members. Therefore, conservative financial reporting produces figures that can be used in contracts to reduce agency costs and litigation risk in family firms [10,11].

Since social networks and business relationships are highly emphasized, establishing good connections with government officials can provide a useful mechanism for firms to avoid economic uncertainty. Several studies support that political connections produce benefits in various forms, such as preferential access to capital, favorable regulatory treatments, and government bailouts [12-14]. However, the establishment of political connections may bring some negative effects to the firms. As firms typically obtain considerable benefits from their political connections (prior research indicates that political connections could provide firms many key resources, including preferential access from creditors [15], preferential support by government-owned banks [16], preferential treatment of government contracts [17]), they have less demand to respond to market pressures regarding their reporting policies [18]. Prior research suggests that politically connected firms face few requirements of information transparency, lower earnings quality, and higher information asymmetry [18,19]. In contrast, if political connection exacerbates rent-extraction from minority shareholders that results in more severe agency problems, then minority shareholders may require family firms to provide better monitoring mechanisms due to price protection [20]. Thus, exploring the moderating role of political connections can create a new avenue of research on family firms.

Taiwan provides an ideal setting to investigate the association among family firms, political connections, and conservative financial reporting. First, family-controlled firms prevail in Taiwan, which has a concentration of family ownership comparable with other countries in East Asia [21,22]. Moreover, Yeh et al. [23] suggested that most of family firms have more than half of the board controlled by families. Family members might use their controlling power to extract their own private benefits, thereby leading to several agency problems, such as family-minority shareholder conflicts [23,24]. Therefore, the detrimental effect of agency problems will be more critical in family firms than nonfamily firms in Taiwan. Second, during Taiwan's economic growth periods, many traditional firms seek a connection with government through owners and top managers participating in public affairs. In this way, these firms can establish a channel of communication to influence governmental decisions (Business Today reported that many Taiwanese family firms are more likely to establish relationships with politicians or government bureaucrats. For example, since 1910, the five largest traditional Taiwanese family firms, such as Gu family group in Lukang, Lin family group in Banciao, Lin family group in Wu feng, Chen family group in Kaohsiung, and Yan family group in Keelung, have built political connections to obtain grant preferential treatment for grants or avoid extra fees and fines), avoid penalties and costs, and, moreover, protect these firms from possible takeover threats. For example, Taishin Financial Holding, one of the biggest banks in Taiwan, had intended to merge Chang Hwa Bank since 2005. Due to the fact that the central government was the major shareholder and had appointed several politicians as directors of the board in Chang Hwa Bank, it took a long time to resolve the takeover deal. However, due to delays in the merger process and unpleasant communications with politicians, Taishin Financial Holding gave up on the merger plan in 2013. Therefore, it is worth testing the different conservative accounting practices between family and nonfamily firms in Taiwan to observe the moderating role of political connections.

Based on the data for Taiwanese listed firms during the period of 1996-2012, we found that political connections negatively moderated the association between family-controlled firms and conservative financial reporting, suggesting that family members with political connections implement less conservative financial reporting. It indicates that due to enjoying some privileges, such as government subsidies, low-cost finance, and tax reductions, politically connected family firms are less likely to release bad news in a timely manner as compared with good news. Moreover, for the 
robustness of these results, we have examined alternative measures of political connections and conservative financial reporting and employed several different methods. The findings are all robust to these alternative approaches.

This paper makes two contributions. First, our study is closely related to that of Chaney et al. [18], who investigated the impact of political connections on the quality of accounting information, which we expand on by examining the effect of political connections on the conservative reporting behavior of family-controlled firms. We found that politically connected family firms become less conservative in their accounting choices, which improves knowledge on how political relationships alter the nature of financial reporting in family firms. Second, unlike prior studies that focused primarily on China, Indonesia, and Malaysia, with less democratic economies [25-28], this study focuses on Taiwan, which is one of the mature Asian democracies. Our findings thus contribute to the research on corporate governance in the Asian capital market.

\section{Literature Review and Hypothesis Development}

\subsection{Conservative Financial Reporting}

Conservative financial reporting serves as a mechanism to improve contracting efficiency because it leads to suitable downward revisions of earnings and book value of net assets, which results in timelier violation of financial covenants [29-31]. This could provide an early sign to debt holders of any possible debt violations [32]. Conservative financial reporting also reduces agency costs and asymmetries in information. Ahmed and Duellman [33] suggested that conservative financial reporting is expected to monitor firms' decision policies. Managers often have motivation to delay the termination of negative net present value projects since such projects tie to their private benefits. Due to the fact that asymmetry verifiability speeds up the recognition of losses, this timely bad news recognition leads to managers applying negative present value projects for their own private benefits $[34,35]$. Hence, conservative financial reporting benefits corporate governance and reduces agency cost, motivating managers to abandon poorly performing projects and cut losses earlier $[4,5]$.

Furthermore, conservative financial reporting can solve the problem of information asymmetry. Several studies suggest that firm managers have motivations to overstate firm's financial reporting due to the manager's intention to keep their position, the value of their stock option and compensation, and the resources they controlled [36,37]. Since there are limits to the extent to which management-provided information could be credible, it becomes easier for managers to manipulate accounting information and report earnings that is less useful to outside investors [38]. Thus, the asymmetrical verification for gains and losses can reduce the manager's motivations to manipulate accounting numbers; thereby decreasing information asymmetry $[34,39,40]$.

\subsection{Family Control and Conservative Financial Reporting}

Following prior research [1-3], the definition of family firms is considered as owner-managed enterprises with family members by blood or marriage, and the families are chief executive officers, directors, or block holders. While most non-family firms are usually characterized as having dispersed ownership and a separation between ownership and control, family firms face fewer owner-manager conflicts and develop a special class of large shareholders, specific ownership structures, a powerful voice, and strong motives to engage in influencing managerial effort [40-42]. However, relative to non-family firms, family firms have severe agency problems stemming from conflicts between dominant and minority (small) shareholders. The families' wealth is disproportionately tied up with the firms and such concentrated ownership results in closer monitoring of management by the controlling families $[43,44]$. As family control increases, families tend to maintain ownership over a longer horizon, or pass it onto descendants or relatives [41]. However, this tight control may allow family self-dealings to go internally unchallenged by other shareholders and make the family more likely to extract rent at the expense of minority shareholders [45]. This may give family owners incentives to use their 
private information to overstate financial performance. In turn, minority shareholders may take actions to protect their personal wealth and avoid benefit extractions undertaken by families $[46,47]$. Requiring conservative accounting is a useful tool to resolve this agency problem to mitigate potential higher agency cost arising from price protection of minority shareholders. As asymmetric verifiability brings timely recognition of losses, it can provide minority shareholders a signal to understand the reason for the losses. Such an asymmetric timeliness in recognition of accounting losses and possible investigations by minority shareholders induce families to be sensible in their management policies. Therefore, conservative financial reporting is a governance mechanism that can decrease a family's intention to overstate and manipulate accounting numbers.

Shareholder litigation is also an essential driver for managers to engage in conservative accounting practices [4]. Litigation leads to asymmetric payoffs, in that overstating the firm's performance or net assets is more likely to increase litigation risk. By understating net assets or performance, conservative accounting decreases a firm's perceived litigation cost and then constrains opportunistic payments to related parties and managers [48,49]. Family owners are more interested in firm survival and have greater incentives for avoiding risky and illegal activities because of the longer investment horizon $[1,50]$. When a family's ownership position is closely tied to the firm, family owners prefer lower litigation risk [51,52]. Moreover, since the family's wealth is disproportionately tied up with the firm, they are more likely to implement a conservative reporting, which can reduce their litigation risk. Basu [48] and Holthausen and Watts [53] suggested that conservative financial reporting is to generate an understatement of net assets by requiring a higher degree of verification for gains than for losses. Blunck [54] found that higher conservative financial reporting is related to a higher dismissal rate of lawsuits and fewer litigation cases. As asymmetric recognition in overstating the firm's net assets could generate higher litigation costs than understating net assets, family firms tend to report conservative accounting numbers to avoid potential lawsuits.

In sum, family firms have concentrated ownership, an interest in long-term viability, and concerns over reputation, therefore, they have a greater incentive to mitigate agency conflicts with minority shareholders and deter potential litigation risks. Recently, Chen et al. [11] provided evidence that family firms are more likely to engage in conservative accounting reporting compared with nonfamily firms. Thus, based on the above discussion, we expect that family firms tend to implement conservative financial reporting and our first hypothesis (H1) was stated as follows:

Hypothesis 1 (H1). Ceteris paribus, family firms tend to have more conservative financial reporting.

\subsection{The Moderating Role of Political Connections}

Political connections have a very significant influence on a firm's economic activities $[55,56]$. Previous research suggests that politically connected firms not only avoid expropriation from the government, but it also enables them to enjoy substantial political benefits [57-59]. As politically connected firms actively build and obtain political resources through appropriate government channels and authority, they can receive ex post financial assistance and preferential corporate bailouts, avoid stringent regulations, and decrease the cost of contracts. Faccio [60] documented that politically connected firms were revealed to pay fewer taxes; thereby benefiting from lower operating costs. Goldman et al. [58] found that politically connected firms receive more government procurement contracts than the firms without political connections. The above evidence supports the notion that the presence of incentives for government officials and bureaucrats to seek in rent-seeking leads firms to obtain an alternative shelter through political connections.

While political connections could provide firms several benefits, the corporate governance literature argues that the establishment of political ties will cause some negative effects to firms [61,62]. Prior studies suggested that political connections lead to lower quality of accounting information and exacerbate information asymmetry [9,49]. Chaney et al. [18] suggested that since government 
bureaucrats provide protection to the firms, politically connected firms care less about the quality of accounting information and pay less attention to accurately portraying the earnings. They also find that managers of politically connected firms have less incentive to respond to market pressures to improve the quality of financial reporting. Chen et al. [49] provided evidence that analysts' earnings forecasts are less accurate for politically connected firms. Additionally, Piotroski et al. [19] found that state-owned enterprises (SOEs) are more likely to hide bad news of expropriation-related activities and suppress the inefficient allocation of resources in order to achieve their political objectives.

While family firms, who have long-term intentions and reputation concerns, have more incentives to provide conservative financial reporting, we argue that political connections may significantly affect a family firm's attitude toward accounting conservatism. First, although government bureaucrats enable family firms to enjoy several privileges and have lower costs of contracts, such as government subsidies, preferential financial assistance, tax reductions, lucrative government contracts, and competitive advantage, [57-59], government bureaucrats are more interested in rent-seeking/extraction and political objectives than maximizing performance and corporate efficiency [63,64]. Since government bureaucrats generally provide protection to politically connected firms who disclose lower earnings quality [26], these firms would receive lighter penalties or even not be penalized under the regulations [19]. Due to weak punishment upon their improper behaviors of earnings disclosure, politically connected family firms are less likely to release bad news in a timely manner. That is, political connections lower family firms' litigation risks and reduce their incentives to apply conservative accounting.

However, from the minority shareholder's point of view, political connections may exacerbate the agency problem between family and minority shareholders. Due to rent-seeking activities of government bureaucrats, they are more interested in their own extraction or political objective [63,64]. Moreover, to ensure the achievement of rent-seeking through political connections, the controlling shareholders may need a concentrated control structure to retain their own decision power. Fan and Wong [22] found that Asian family firms have lower quality of reported earnings. They stated that the findings were mainly driven by an entrenchment effect, where family firms are more likely to manipulate earnings to hide expropriation activities. In addition, Gul [65] suggested that auditors input a greater effort for the firms with political connections due to higher information asymmetry. Therefore, it will exacerbate family-minority shareholder agency conflicts. Due to the fact that minority shareholders lack timely inside information, have weaker power to monitor families, and exercise less control over families' activities, they have a greater demand for conservative financial reporting to avoid benefit extractions undertaken by families and government officials.

In summary, politically connected family firms may implement less conservative financial reporting if they face lower punishment for improper information disclosure and lower downside default risk. On the other hand, politically connected family firms may need more conservative accounting if minority shareholders perceive the severe entrenchment effect by families and government bureaucrats. As a result of these competing explanations, we made a nondirectional prediction (H2) as follows:

Hypothesis 2 (H2). Ceteris paribus, political connections will moderate the effect of family control on conservative financial reporting.

\section{Research Design and Methodology}

\subsection{Measures of Family Firm}

A family firm refers to an enterprise in which the family can exert a substantial influence by virtue of the ownership structure and/or seats on the managerial/supervisory board. Following prior research [2], we defined a founding family's influence, FAM, taking a value of one if family members, by blood or marriage, are chief executive officers, directors, or block holders; otherwise, FAM took a value of zero. In addition, the continuous variable, FAMOWN, is defined as the fractional equity ownership of the family. 


\subsection{Measures of Political Connections}

To capture the political influence of government officials, we followed Faccio et al. [55] and Fan et al. [22] and defined political connections as an indicator variable, PC, which takes the value of one if a firm's largest shareholders, senior officers, or board members currently satisfy any one of the criteria of political connection as follows: (1) a former official in central or local government; (2) a current or former congressperson or elected representative; or (3) a current or former party representative, such as party chief, party secretary, or party committee member.

\subsection{Methodology of Testing Model}

Based on Khan and Watts' [66], our measure of conservative financial reporting was firm-yearspecific asymmetric timeliness score. First, we established Basu's [48] asymmetric timeliness measure, which regresses earnings on return and allows the return coefficient to vary with the sign of the return.

$$
N I_{i t}=\beta_{0}+\beta_{1} R E T_{i t}+\beta_{2} N E G_{i t}+\beta_{3} R E T_{i t} * N E G_{i t}+\varepsilon(1)
$$

where, for firm $i$ and period $t: N I$ is the net income before extraordinary items are deflated by the market value of the equity at the beginning of the period; RET is the buy-and-hold return over the fiscal year; and NEG is an indicator variable coded to one when RET is negative, and zero otherwise. In Equation (1), $\beta_{1}$ captures the timeliness of earnings with respect to positive returns, and $\beta_{1}+\beta_{3}$ capture the timeliness of earnings with respect to negative returns. If $\beta_{1}+\beta_{3}>\beta_{1}$ (or $\beta_{3}>0$ ), it will be conservative reported earnings; that is, a positive and significant $\beta_{3}$ represents earnings that reflect bad news more quickly than good news and, hence, is the measure of conservatism (i.e., the asymmetric timeliness coefficient).

Second, we developed an estimation of the timeliness of good news (G_Score) and the incremental timeliness of bad news (C_Score) as linear functions of size, market-to-book value, and financial leverage.

$$
\begin{aligned}
& \text { G_Score }_{i t}=\beta_{1}=\mu_{1}+\mu_{2} M V E_{i t}+\mu_{3} M T B_{i t}+\mu_{4} L E V_{i t} \\
& \text { C_Score }_{i t}=\beta_{3}=\lambda_{1}+\lambda_{2} M V E_{i t}+\lambda_{3} M T B_{i t}+\lambda_{4} L E V_{i t}
\end{aligned}
$$

where, for firm $i$ and period $t: M V E$ is the natural logarithm for the market value of the equity; MTB is the market value of the equity divided by the book value of the equity; $L E V$ is the total liabilities divided by total assets; and the empirical estimators of $\mu_{1}-\mu_{4}$ and $\lambda_{1}-\lambda_{4}$, are constant across all firms, but vary over time. After estimating $\beta_{1}$ and $\beta_{3}$ in Equations (2) and (3), we placed them into Equation (1) to yield Equation (4) as follows:

$$
\begin{aligned}
N I_{i t} & =\beta_{0}+R E T_{i t} *\left(\mu_{1}+\mu_{2} M V E_{i t}+\mu_{3} M T B_{i t}+\mu_{4} L E V_{i t}\right) \\
& +\beta_{2} N E G_{i t}+R E T_{i t} * N E G_{i t} *\left(\lambda_{1}+\lambda_{2} M V E_{i t}+\lambda_{3} M T B_{i t}+\lambda_{4} L E V_{i t}\right) \\
& +\left(\delta_{1} M V E_{i t}+\delta_{2} M T B_{i t}+\delta_{3} L E V_{i t}+\delta_{4} N E G_{i t} * M V E_{i t}\right. \\
& \left.+\delta_{5} N E G_{i t} * M T B_{i t}+\delta_{6} N E G_{i t} * L E V_{i t}\right)+\varepsilon
\end{aligned}
$$

Following Khan and Watts [66], we included an additional term in the last parenthesis of Equation (4) to control for the firm's characteristics separately (the main effect). We first estimated Equation (4) in annual cross-sections to obtain the coefficient estimates for $\lambda_{1}-\lambda_{4}$, which we then applied to Equation (3) to calculate the C_Score: a higher C_Score represents a higher degree of conservatism.

To test the hypothesis, we applied the firm-specific timeliness measure of conservatism in the following regression:

$$
\text { C_Score } i t=\theta_{0}+\theta_{1} \text { FAMOWN }_{i t}+\theta_{2} \text { PC }_{i t}+\theta_{3} \text { FAMOWN }_{i t} * \text { PC }_{i t}+\theta_{4} \text { CONTROLS }_{i t}+\varepsilon
$$

where, for firm $i$ and period $t, C_{-}$Score is the firm-specific measure of conservatism; $P C$ is the political connections indicator; and CONTROLS is a vector of control variables. This vector includes: PCOWN, 
the politician ownership; OUTOWN, the fractional equity ownership of the outside largest shareholder; INST, the fractional equity ownership of the institutional shareholder; SIZE, the natural logarithm for the book value of total assets; $L E V$, the total liabilities divided by total assets; $M T B$, the market value of the equity divided by the book value of the equity; $C F O$, the cash flows from operating activities scaled by lagged total assets; $L A G N I$, prior net income scaled by market value of equity; $A G E$, the number of listed firm years; VOLRET, the standard deviation for the daily stock returns; LINC, the depreciation expense scaled by lagged total assets; and LIT, an indicator variable set to one if the firm is in a technology industry, otherwise zero.

The control variables were identified from prior literature. For ownership structure, we added politician ownership $(P C O W N)$ as control variable. Prior studies have suggested that politician-owned firms are less likely to implement conservative financial reporting due to lenders being less concerned with downside default risk and protection from public scrutiny [67-69]. In addition, we controlled for the ownership of outside shareholders (OUTOWN) and institutional shareholders (INST), since external monitoring mechanisms could exhibit a higher degree of accounting conservatism [70]. For firm specific characteristics, we controlled for firm size (SIZE), as previous studies suggest that larger firms have a lower asymmetric timeliness of earnings [70]. Ahmed and Duellman [71] found that firms with greater bondholder-shareholder conflicts evidenced a higher demand for conservative financial reporting; thus, we also controlled for financial leverage $(L E V)$ in the regression. In addition, we included growth opportunities $(M T B)$ as prior a study found a negative relation between growth and conservatism [72,73]. We controlled for profitability using operating cash flow (CFO) as a proxy as well since Ahmed and Duellman [71] found that profitable firms tend to use conservative accounting practices. Moreover, Khan and Watts [66] suggested that the characteristics of a firm's information environment could affect conservatism, which increased with firm-specific uncertainty and decreased with firm age; thus, we included prior net income (LAGNI), return volatility (VOLRET), and firm age (AGE) to control for this effect. Furthermore, Khan and Watts [66] found that conservative financial reporting is positively related to investment uncertainty; therefore, we included the length of the investment cycle (LINC) in the model. A shigh technology firms face greater risks of shareholder litigation and greater discretionary expenditures affected by accounting standards, such as the recognition of research and development (R\&D) costs and potential loss of patent litigation [74,75], such firms can use conservative accounting to reduce anticipated litigation costs from shareholders; thus, we included an indicator variable to control for firms facing high litigation risks (LIT). Finally, we controlled for yearly and industry sector fixed effects, which both account for the systematic time period and controls for any omitted industry factor.

In Equation (5), the primary coefficient of interest was $\theta_{3}$. We expected the sign of $\theta_{3}$ to be negative (or positive) if political connections weaken (strengthen) the incentive in family firms to engage in conservative financial reporting.

\section{Data and Empirical Results}

\subsection{Data}

Our initial sample (1996-2012) was obtained from the Taiwan Economic Journal (TEJ) database for publicly listed firms, which provides data on corporate governance structures since 1996, as well as financial and stock price data. The initial sample consisted of non-financial firms listed with 21,393 firm-year observations. A total of 6550 firm-year observations were eliminated due to insufficient stock price data while another 906 and 60 firm-year observations were deleted due to insufficient financial data (NI, CFO) and firm age (AGE), respectively. The final sample comprised 13,877 firm-year observations. Data related to founding families were hand-collected from annual reports, company prospectuses, and business groups in Taiwan. Information related to firms' political connections (as defined by their largest shareholders or senior managers and directors being former or current government officials) was hand-collected from the minutes of shareholders' meetings, annual reports, 
the National Central Election Commission, the National Central Library Gazette Online, and political party websites. The initial sample consisted of non-financial firms listed with 21,393 firm-year observations. A total of 6550 firm-year observations were eliminated due to insufficient stock price data while another 906 and 60 firm-year observations were deleted because of insufficient financial data (NI, $C F O)$ and firm age $(A G E)$, respectively. The final sample comprised 13,877 firm-year observations.

\subsection{Descriptive Statistics}

Table 1 presents the descriptive statistics for all variables. The mean (median) net income scaled by market value of equity (NI) in our sample was $1.3 \%(5 \%)$ and it is noted that the distribution of NI is left-skewed, which is consistent with conservative financial reporting. Although Taiwan is a code-law and Asian country, it has a higher percentage (49.4\%) of technology companies and an advanced economy. For example, the International Monetary Fund has classified Taiwan as an advanced economy since 2009. Morgan Stanley Capital International Inc. (MSCI) included Taiwan in the list of developed markets under review as part of the 2010 Annual Market Classification Review. Additionally, Chandra [75] found that due to higher shareholder litigation risk, technology firms have greater income conservatism. Therefore, different from right-skewed net income distribution in both the code-law and Asian categories, it is left-skewed net income distribution in Taiwan, which is consistent with Chi and Wang's finding [66]. The mean of annual buy-and-hold return, RET was $18.2 \%$; furthermore, the descriptive statistics of NEG indicate that approximately $50 \%$ of the sample revealed a negative buy-and-hold return over the fiscal year (mean value of NEG equals 0.495 ). The C_Score was 0.085 (0.079), which is consistent with previous research. In addition, family firms, FAM, and politically connected firms, $P C$, constituted $41.5 \%$ and $19.2 \%$ of the sample, respectively. We found that the mean (median) value on politician ownership (PCOWN), outside shareholders' ownership (OUTOWN), and institutional shareholders' ownership (INST) were1.4\% (0.4\%), 3.3\% (1.8\%), and 8.9\% $(3.4 \%)$, respectively. Moreover, for firm characteristics, the mean firm size (SIZE) had a log book value of total assets of 15.224 , which is equivalent to a book value of NTD $\$ 4995.250$ million. The average firm finances $(L E V)$ were about $34 \%$ of their reported assets with debt while the mean market-to-book ratio (MTB) was1.622. The mean value of operating cash flow (CFO) and prior income scaled by market value of equity ( $L A G N I)$ were about $5.9 \%$ of total assets and 0.045 , respectively. The mean (median) standard deviation of daily stock returns (VOLRET) was 0.136 (0.120). Finally, about $49 \%$ of our sample observation exhibited high litigation-risk industries, and the mean firm age (AGE) was9.435 years.

Table 2 reports Pearson's correlation matrix among the variables used in estimating the models. As expected, the C_Score had a significantly positive correlation with FAM (0.093) and FAMOWN (0.103), but significantly negative correlation with PCOWM (-0.019). We also found that FAMOWN was positively related to INST (0.088) and LEV (0.306), whereas it was negatively related to politician ownership (PCOWM) and outsider ownership (OUTOWN), firm size (SIZE), growth rate (MTB), firm age $(A G E)$, and technology industry (LIT). 
Table 1. Descriptive statistics.

\begin{tabular}{cccccc}
\hline & Mean & Std. Dev & P25 & Median & P75 \\
\hline NI & 0.013 & 0.273 & 0.003 & 0.050 & 0.094 \\
RET & 0.182 & 0.833 & -0.278 & 0.005 & 0.376 \\
NEG & 0.495 & 0.500 & 0.000 & 0.000 & 1.000 \\
C_Score & 0.085 & 0.082 & 0.027 & 0.079 & 0.137 \\
FAM & 0.415 & 0.493 & 0.000 & 0.000 & 1.000 \\
FAMOWN & 0.130 & 0.185 & 0.000 & 0.000 & 0.255 \\
PCOWN & 0.014 & 0.062 & 0.000 & 0.000 & 0.000 \\
OUTOWN & 0.033 & 0.048 & 0.000 & 0.018 & 0.043 \\
INST & 0.089 & 0.135 & 0.002 & 0.034 & 0.113 \\
PC & 0.192 & 0.395 & 0.000 & 0.000 & 0.000 \\
SIZE & 15.224 & 1.318 & 14.317 & 15.065 & 15.952 \\
LEV & 0.340 & 0.170 & 0.251 & 0.372 & 0.489 \\
MTB & 1.622 & 2.439 & 0.831 & 1.256 & 1.925 \\
CFO & 0.059 & 0.144 & 0.009 & 0.057 & 0.117 \\
LAGNI & 0.045 & 0.731 & 0.006 & 0.049 & 0.096 \\
AGE & 9.469 & 8.431 & 4.000 & 7.000 & 12.000 \\
VOLRET & 0.136 & 0.075 & 0.087 & 0.120 & 0.166 \\
LINC & 0.025 & 0.027 & 0.007 & 0.017 & 0.033 \\
LIT & 0.494 & 0.500 & 0.000 & 0.000 & 1.000
\end{tabular}

$\mathrm{NI}$ is net income before extraordinary items scaled by lagged market value of equity. RET is buy and hold return over the fiscal year. NEG is an indicator that equals one if $R E T$ is negative and zero otherwise. C_Score is the firm-year level conservatism score. FAM is an indicator that equals one if the firm is a family firm and zero otherwise; FAMOWN is family ownership; PCOWN is political ownership; OUTOWN is the fractional equity ownership of the outside largest shareholder; INST is the fractional equity ownership of the institutional shareholder; LAGNI is prior net income scaled by market value of equity; $P C$ is an indicator that equals one if a firm has a politically connected largest shareholders, top management, or board members and zero otherwise. SIZE is the natural logarithm of total assets. $L E V$ is total debt divided by total assets. MTB is the market-to-book ratio. CFO is operating cash flow scaled by lagged total assets. AGE is the number of years since the firm was listed. VOLRET is the standard deviation of daily stock returns. LINC is depreciation expense scaled by lagged total assets. LIT is an indicator that equals one if the firm is in a technology industry and zero otherwise. 
Table 2. Correlation matrix.

\begin{tabular}{|c|c|c|c|c|c|c|c|c|c|c|c|c|c|c|c|c|}
\hline & 1 & 2 & 3 & 4 & 5 & 6 & 7 & 8 & 9 & 10 & 11 & 12 & 13 & 14 & 15 & 16 \\
\hline 1 C_Score & 1.000 & & & & & & & & & & & & & & & \\
\hline $2 \bar{F} A M$ & 0.093 & 1.000 & & & & & & & & & & & & & & \\
\hline 3 FAMOWN & 0.103 & 0.837 & 1.000 & & & & & & & & & & & & & \\
\hline 4 PCOWN & -0.019 & -0.023 & -0.039 & 1.000 & & & & & & & & & & & & \\
\hline 5 OUTOWN & -0.014 & -0.088 & -0.116 & 0.058 & 1.000 & & & & & & & & & & & \\
\hline 6 INST & 0.231 & 0.088 & 0.106 & -0.168 & -0.072 & 1.000 & & & & & & & & & & \\
\hline $7 P C$ & -0.013 & -0.077 & -0.085 & -0.369 & 0.036 & -0.105 & 1.000 & & & & & & & & & \\
\hline 8 SIZE & -0.165 & -0.037 & -0.087 & 0.120 & -0.082 & 0.479 & 0.108 & 1.000 & & & & & & & & \\
\hline $9 L E V$ & 0.306 & 0.080 & 0.074 & 0.018 & 0.046 & -0.073 & 0.023 & 0.134 & 1.000 & & & & & & & \\
\hline 10 МТВ & -0.112 & -0.026 & -0.027 & 0.034 & 0.049 & 0.088 & 0.002 & -0.044 & 0.034 & 1.000 & & & & & & \\
\hline $11 C F O$ & -0.272 & 0.007 & -0.011 & 0.015 & -0.015 & 0.139 & 0.018 & 0.075 & -0.241 & 0.069 & 1.000 & & & & & \\
\hline 12LAGNI & -0.110 & 0.025 & 0.009 & 0.001 & -0.014 & 0.040 & 0.002 & 0.072 & -0.088 & 0.004 & 0.057 & 1.000 & & & & \\
\hline 13 AGE & -0.112 & -0.127 & -0.127 & 0.052 & -0.058 & 0.161 & 0.082 & 0.388 & -0.007 & -0.076 & -0.068 & -0.042 & 1.000 & & & \\
\hline 14 VOLRET & 0.190 & 0.037 & 0.012 & -0.050 & 0.012 & -0.142 & -0.032 & -0.149 & 0.164 & 0.111 & -0.078 & -0.104 & -0.100 & 1.000 & & \\
\hline 15 LINC & 0.039 & 0.026 & -0.007 & 0.030 & 0.055 & 0.122 & 0.022 & 0.130 & 0.002 & 0.013 & 0.174 & -0.005 & -0.094 & 0.053 & 1.000 & \\
\hline 16 LIT & 0.187 & -0.176 & -0.209 & -0.076 & 0.015 & 0.056 & -0.047 & -0.107 & -0.211 & 0.073 & 0.127 & 0.033 & -0.307 & 0.095 & 0.081 & 1.000 \\
\hline
\end{tabular}

See Table 1 for definitions of all variables. Pearson coefficients in lower left. The figure indicates significance at the $5 \%$ or better level (two-tailed test). 


\subsection{Main Test}

Table 3 reveals the estimation results of Equation (5) and shows that the coefficients on FAMOWN were significantly positive $(p<0.01)$ in Columns (1) and (2). These results indicate that greater family ownership was related to higher accounting conservatism, which supports our hypothesis 1. In addition, the coefficient on interaction term, $F A M O W N^{*} P C$, was negative (coefficient $=-0.092$ ) and significant $(p<0.01)$ in column $(2)$, indicating that political connections can negatively moderate the association between family ownership and conservative financial reporting, which supports our hypothesis 2 . That is, politically connected family firms use conservative accounting practices less than nonpolitically connected firms.

Table 3. Familycontrol, political connection, and Khan and Watt's conservatism score.

\begin{tabular}{|c|c|c|c|}
\hline & \multirow[b]{3}{*}{ Expected Sign } & \multicolumn{2}{|c|}{ Dependent Variable $=$ C_Score } \\
\hline & & (1) & (2) \\
\hline & & $\begin{array}{c}\text { Coef. } \\
\text { (t-stat.) }\end{array}$ & $\begin{array}{c}\text { Coef. } \\
\text { (t-stat.) }\end{array}$ \\
\hline FAMOWN & + & $\begin{array}{l}0.166^{* * *} \\
(10.98)\end{array}$ & $\begin{array}{l}0.058^{* * *} \\
(4.83)\end{array}$ \\
\hline$P C$ & - & & $\begin{array}{l}-0.015 \\
(-1.48)\end{array}$ \\
\hline$F A M O W N^{*} P C$ & - & & $\begin{array}{l}-0.092^{* *} \\
(-2.50)\end{array}$ \\
\hline PCOWN & - & $\begin{array}{l}-0.000 \\
(-0.21)\end{array}$ & $\begin{array}{l}-0.000 \\
(-0.15)\end{array}$ \\
\hline OUTOWN & + & $\begin{array}{l}-0.078 \\
(-1.04)\end{array}$ & $\begin{array}{l}-0.079 \\
(-1.04)\end{array}$ \\
\hline INST & + & $\begin{array}{l}0.107^{* * *} \\
(2.94)\end{array}$ & $\begin{array}{l}0.106^{* * *} \\
(2.91)\end{array}$ \\
\hline SIZE & - & $\begin{array}{l}-0.043^{* * *} \\
(-11.20)\end{array}$ & $\begin{array}{l}-0.043^{* * *} \\
(-11.19)\end{array}$ \\
\hline$L E V$ & + & $\begin{array}{l}0.765^{* * *} \\
(30.40)\end{array}$ & $\begin{array}{l}0.765^{* * *} \\
(30.43)\end{array}$ \\
\hline MTB & - & $\begin{array}{l}-0.026 \\
(-2.13)\end{array}$ & $\begin{array}{l}-0.026^{* *} \\
(-2.13)\end{array}$ \\
\hline CFO & + & $\begin{array}{l}0.132^{* * *} \\
(3.21)\end{array}$ & $\begin{array}{l}0.133^{* * * *} \\
(3.21)\end{array}$ \\
\hline$L A G N I$ & $?$ & $\begin{array}{l}-0.005 \\
(-1.58)\end{array}$ & $\begin{array}{l}-0.005 \\
(-1.39)\end{array}$ \\
\hline$A G E$ & - & $\begin{array}{l}-0.001^{* * *} \\
(-2.92)\end{array}$ & $\begin{array}{l}-0.002^{* * *} \\
(-3.67)\end{array}$ \\
\hline VOLRET & + & $\begin{array}{l}0.777^{* * *} \\
(8.99)\end{array}$ & $\begin{array}{l}0.777^{* * * *} \\
(8.99)\end{array}$ \\
\hline LINC & + & $\begin{array}{c}0.598^{* * * *} \\
(4.95)\end{array}$ & $\begin{array}{l}0.598^{* * * *} \\
(4.94)\end{array}$ \\
\hline LIT & + & $\begin{array}{l}0.002 \\
(0.16)\end{array}$ & $\begin{array}{l}0.002 \\
(0.14)\end{array}$ \\
\hline Intercept & & $\begin{array}{l}0.497^{* * *} \\
(8.19)\end{array}$ & $\begin{array}{l}0.496^{* * * *} \\
(8.20)\end{array}$ \\
\hline $\begin{array}{c}\text { Year/Industry Fixed Effect } \\
\text { Adjusted } R^{2}\end{array}$ & & $\begin{array}{l}\text { Included } \\
0.485\end{array}$ & $\begin{array}{c}\text { Included } \\
0.485\end{array}$ \\
\hline
\end{tabular}

See Table 1 for definitions of all variables. ${ }^{*},{ }^{* *}$, and ${ }^{* * *}$ denotes significance at the $10 \%, 5 \%$, and $1 \%$ levels, respectively (two-tailed test). Robust t-statistics (clustered standard errors by firm) are shown in parentheses.

With respect to the control variables, as predicted, we found that firms tend to use conservative accounting when they have a larger proportion of institutional shareholdings (INST), smaller size (SIZE), higher financial leverage ( $L E V)$, and more cash holdings (CFO). In addition, consistent with 
Khan and Watts [66], younger firms $(A G E)$ and those with larger deviations of daily stock returns (VOLRET) are more likely to implement conservative financial reporting due to higher investment uncertainty. These results are consistent with the previous studies $[29,33,34]$.To mitigate the impact of extreme outliers, we further winsorized our observations in the top $1 \%$ and bottom $1 \%$ of the empirical distribution for all variables. Our results using winsorized observations remained unchanged.

\subsection{Active Family Management}

Several family attributes may change over time as management (CEO) positions change [73]. The literature argues that founders and descendants generate a different firm performance [74]. Empirical evidence indicates that a founder CEO performs better, whereas a descendant CEO significantly underperform compared with nonfamily firms [75]. Thus, we examined whether family involvement in the management of a firm affects accounting conservatism. To conduct this analysis, we classified family firms into three categories: those with a founder CEO (FCEO), a descendant CEO (DCEO), and a hired CEO (HCEO). FAMOWN is replaced by each of these three indicators in the firm-year conservatism model, i.e., Equation (5).

Column (1) of Table 4 shows that the coefficients on FCEO (coefficient $=0.077$ ), DCEO (coefficient $=0.049$ ), and HCEO (coefficient $=0.103$ ) were significantly positive, suggesting that each of these three types of CEO in family firms tends to use more conservative accounting practices than those in nonfamily firms. Furthermore, as shown in Column (2) of Table 6, the coefficients on FCEO*PC (coefficient $=-0.035$ ) and $D C E O^{*} P C$ (coefficient $=-0.029$ ) were significantly negative, whereas the coefficient on $H C E O^{*} P C$ was insignificant. That is, political connections will weaken the family CEOs' incentives to adopt conservative accounting, but have no influence on hired CEOs. A possible explanation regarding this result is that, different from family CEOs, hired CEOs adopt an aggressive accounting policy as they may otherwise face discipline from the external labor market when they are unemployed by family firms (Desai et al., 2006). Another possible explanation is that hired CEOs increase Type I agency conflicts between family owners and managers and therefore family owners require more conservative accounting. Therefore, political connections will cause firms with a family CEO to implement less conservative accounting practices relative to firms with nonfamily CEOs.

Table 4. Active family management.

\begin{tabular}{|c|c|c|c|}
\hline & \multirow[b]{3}{*}{ Expected Sign } & \multicolumn{2}{|c|}{ Dependent variable $=$ C_Score } \\
\hline & & (1) & (2) \\
\hline & & $\begin{array}{c}\text { Coef. } \\
\text { (t-stat.) }\end{array}$ & $\begin{array}{c}\text { Coef. } \\
\text { (t-stat.) }\end{array}$ \\
\hline FCEO & + & $\begin{array}{c}0.077^{* * * *} \\
(10.48)\end{array}$ & $\begin{array}{c}0.076^{* * * *} \\
(10.30)\end{array}$ \\
\hline$D C E O$ & + & $\begin{array}{c}0.049^{* * * *} \\
(8.18)\end{array}$ & $\begin{array}{c}0.055^{* * * *} \\
(8.12)\end{array}$ \\
\hline HCEO & + & $\begin{array}{c}0.103^{* * * *} \\
(13.31)\end{array}$ & $\begin{array}{l}0.110^{* * *} \\
(12.90)\end{array}$ \\
\hline$P C$ & - & & $\begin{array}{l}-0.009 \\
(-0.78)\end{array}$ \\
\hline$F C E O * P C$ & - & & $\begin{array}{l}-0.035^{* *} \\
(-2.05)\end{array}$ \\
\hline$D C E O * P C$ & - & & $\begin{array}{c}-0.029^{* *} \\
(-1.96)\end{array}$ \\
\hline$H C E O^{*} P C$ & - & & $\begin{array}{l}-0.023 \\
(-1.38)\end{array}$ \\
\hline PCOWN & - & $\begin{array}{l}-0.029 \\
(-0.68)\end{array}$ & $\begin{array}{l}-0.031 \\
(-0.67)\end{array}$ \\
\hline
\end{tabular}


Table 4. Cont.

\begin{tabular}{|c|c|c|c|}
\hline & \multirow[b]{3}{*}{ Expected Sign } & \multicolumn{2}{|c|}{ Dependent variable $=$ C_Score } \\
\hline & & (1) & (2) \\
\hline & & $\begin{array}{c}\text { Coef. } \\
\text { (t-stat.) }\end{array}$ & $\begin{array}{c}\text { Coef. } \\
\text { (t-stat.) }\end{array}$ \\
\hline OUTOWN & + & $\begin{array}{l}-0.059 \\
(-0.79)\end{array}$ & $\begin{array}{l}-0.061 \\
(-0.81)\end{array}$ \\
\hline INST & + & $\begin{array}{c}0.093^{* * *} \\
(2.55)\end{array}$ & $\begin{array}{c}0.094^{* *} \\
(2.57)\end{array}$ \\
\hline SIZE & - & $\begin{array}{l}-0.046^{* * *} \\
(-11.87)\end{array}$ & $\begin{array}{l}-0.046^{* * *} \\
(-11.87)\end{array}$ \\
\hline$L E V$ & + & $\begin{array}{c}0.758^{* * *} \\
(30.18)\end{array}$ & $\begin{array}{l}0.759^{* * * *} \\
(30.21)\end{array}$ \\
\hline MTB & - & $\begin{array}{l}-0.026^{* *} \\
(-2.13)\end{array}$ & $\begin{array}{c}-0.026^{* *} \\
(-2.13)\end{array}$ \\
\hline CFO & + & $\begin{array}{c}0.136^{* * *} \\
(3.28)\end{array}$ & $\begin{array}{c}0.136^{* * * *} \\
(3.29)\end{array}$ \\
\hline LAGNI & $?$ & $\begin{array}{l}-0.006^{*} \\
(-1.77)\end{array}$ & $\begin{array}{l}-0.006^{*} \\
(-1.79)\end{array}$ \\
\hline$A G E$ & - & $\begin{array}{c}-0.001^{* * *} \\
(-3.16)\end{array}$ & $\begin{array}{c}-0.001^{* * *} \\
(-3.18)\end{array}$ \\
\hline VOLRET & + & $\begin{array}{c}0.803^{* * *} \\
(9.26)\end{array}$ & $\begin{array}{c}0.803^{* * * *} \\
(9.27)\end{array}$ \\
\hline LINC & + & $\begin{array}{l}0.599 \\
(4.96)\end{array}$ & $\begin{array}{l}0.600 \\
(4.95)\end{array}$ \\
\hline LIT & + & $\begin{array}{l}0.001 \\
(0.90)\end{array}$ & $\begin{array}{l}0.001 \\
(0.90)\end{array}$ \\
\hline Intercept & & $\begin{array}{c}0.529^{* * * *} \\
(8.91)\end{array}$ & $\begin{array}{c}0.528^{* * *} \\
(8.89)\end{array}$ \\
\hline Year/Industry Fixed Effect & & Included & Included \\
\hline Adjusted $\mathrm{R}^{2}$ & & 0.485 & 0.485 \\
\hline Number of obs. & & 13,877 & 13,877 \\
\hline
\end{tabular}

FCEO is an indicator variable that equals one if the founder serves as the firm's CEO, otherwise 0; DCEO is an indicator variable that equals one if a founder's descendent serves as the CEO, otherwise 0; and $H C E O$ is an indicator variable that equals one if an outsider serves as the CEO, otherwise 0.See Table 1 for definitions of other variables. ${ }^{* * *}$, and ${ }^{* * *}$ denote significance at the $10 \%, 5 \%$, and $1 \%$ levels respectively (two-tailed test). Robust $\mathrm{t}$-statistics (clustered standard errors by firm) are shown in parentheses.

\subsection{Robustness Tests}

4.5.1. Controlling for State-run orPolitical Party-run Firms, the Endogeneity Problem, and Alternative Definitions of Family Firm

In this section, we provide additional robustness checks to supplement the results obtained in our main analysis. First, there were many state-run or political party-run (e.g., KMT-run) firms in our sample. As these firms are controlled by the government or a political party, the results may be confounded by their own political connections. To control for any possible confounding effect of political ownership, we deleted 288 observations whose largest shareholder is government and 18 observations whose largest shareholder is a political party. Thus, in Column (1) of Table 5, we re-run Equation (5) and obtain similar results as previous findings. 
Table 5. Controlling for state-run or political-party run firms, endogeneity problem, and alternative definitions of family firm.

\begin{tabular}{|c|c|c|c|c|c|c|}
\hline & \multirow[b]{4}{*}{$\begin{array}{c}\text { Expected } \\
\text { Sign }\end{array}$} & \multicolumn{5}{|c|}{ Dependent Variable $=$ C_Score } \\
\hline & & $\begin{array}{l}\text { Deleted } \\
\text { State } \\
\text { Run(288) } \\
\text { and KMT } \\
\text { Run(18) } \\
\text { Sample }\end{array}$ & $\begin{array}{l}\text { Controlling } \\
\text { for } \\
\text { Endogeneity } \\
\text { Problem }\end{array}$ & $\begin{array}{c}\text { Family } \\
\text { Chairman } \\
\text { Having } \\
\text { Political } \\
\text { Connection }\end{array}$ & $\begin{array}{c}\text { Family } \\
\text { CEO } \\
\text { Having } \\
\text { Political } \\
\text { Connection }\end{array}$ & $\begin{array}{c}\text { Family } \\
\text { Board } \\
\text { Director } \\
\text { Having } \\
\text { Political } \\
\text { Connection }\end{array}$ \\
\hline & & (1) & (2) & (3) & (4) & (5) \\
\hline & & $\begin{array}{c}\text { Coef. } \\
\text { (t-stat.) }\end{array}$ & $\begin{array}{c}\text { Coef. } \\
\text { (t-stat.) }\end{array}$ & $\begin{array}{c}\text { Coef. } \\
\text { (t-stat.) }\end{array}$ & $\begin{array}{c}\text { Coef. } \\
\text { (t-stat.) }\end{array}$ & $\begin{array}{c}\text { Coef. } \\
\text { (t-stat.) }\end{array}$ \\
\hline FAMOWN & $+/-$ & $\begin{array}{l}0.173^{* * *} \\
(10.55)\end{array}$ & $\begin{array}{c}0.305^{* * *} \\
(8.75)\end{array}$ & $\begin{array}{c}0.168^{* * *} \\
(10.88)\end{array}$ & $\begin{array}{c}0.164^{* * *} \\
(10.78)\end{array}$ & $\begin{array}{c}0.175^{* * *} \\
(10.97)\end{array}$ \\
\hline$P C$ & - & $\begin{array}{l}-0.001 \\
(-0.16)\end{array}$ & & $\begin{array}{l}-0.015^{*} \\
(-1.88)\end{array}$ & $\begin{array}{l}-0.008 \\
(-0.37)\end{array}$ & $\begin{array}{l}-0.003 \\
(-0.14)\end{array}$ \\
\hline$F A M O W N^{*} P C$ & $+/-$ & $\begin{array}{l}-0.072^{*} \\
(-1.86)\end{array}$ & & $\begin{array}{c}-0.104^{* *} \\
(-2.01)\end{array}$ & $\begin{array}{l}-0.073^{*} \\
(-1.87)\end{array}$ & $\begin{array}{l}-0.058^{*} \\
(-1.85)\end{array}$ \\
\hline PC_hat & - & & $\begin{array}{c}-2.185^{* * *} \\
(-16.78)\end{array}$ & & & \\
\hline FAMOWN*PC_hat & $+/-$ & & $\begin{array}{c}-1.314^{* * *} \\
(-7.72)\end{array}$ & & & \\
\hline PCOWN & - & $\begin{array}{l}-0.029 \\
(-0.43)\end{array}$ & $\begin{array}{l}-0.014 \\
(-0.22)\end{array}$ & $\begin{array}{l}-0.059 \\
(-1.22)\end{array}$ & $\begin{array}{l}-0.036 \\
(-0.82)\end{array}$ & $\begin{array}{l}-0.005 \\
(-0.11)\end{array}$ \\
\hline OUTOWN & + & $\begin{array}{l}-0.082 \\
(-1.03)\end{array}$ & $\begin{array}{l}-0.054 \\
(-0.68)\end{array}$ & $\begin{array}{l}-0.076 \\
(-1.00)\end{array}$ & $\begin{array}{l}-0.075 \\
(-0.98)\end{array}$ & $\begin{array}{l}-0.075 \\
(-0.99)\end{array}$ \\
\hline INST & + & $\begin{array}{c}0.118^{* * * *} \\
(2.90)\end{array}$ & $\begin{array}{l}0.051 \\
(1.24)\end{array}$ & $\begin{array}{c}0.102^{* * * *} \\
(2.76)\end{array}$ & $\begin{array}{c}0.100^{* * *} \\
(2.73)\end{array}$ & $\begin{array}{c}0.103^{* * *} \\
(2.80)\end{array}$ \\
\hline SIZE & - & $\begin{array}{c}-0.044^{* * *} \\
(-10.89)\end{array}$ & $\begin{array}{l}-0.004 \\
(-0.75)\end{array}$ & $\begin{array}{l}-0.044^{* * *} \\
(-11.30)\end{array}$ & $\begin{array}{c}-0.044^{* * *} \\
(-11.33)\end{array}$ & $\begin{array}{l}-0.044^{* * *} \\
(-11.36)\end{array}$ \\
\hline LEV & + & $\begin{array}{l}0.765^{* * *} \\
(29.81)\end{array}$ & $\begin{array}{l}0.841^{* * *} \\
(31.55)\end{array}$ & $\begin{array}{l}0.765^{* * *} \\
(30.39)\end{array}$ & $\begin{array}{l}0.764^{* * *} \\
(30.39)\end{array}$ & $\begin{array}{c}0.764^{* * *} \\
(30.37)\end{array}$ \\
\hline MTB & - & $\begin{array}{l}-0.026^{* *} \\
(-2.12)\end{array}$ & $\begin{array}{l}-0.022^{*} \\
(-1.76)\end{array}$ & $\begin{array}{c}-0.026^{* *} \\
(-2.14)\end{array}$ & $\begin{array}{c}-0.026^{* *} \\
(-2.14)\end{array}$ & $\begin{array}{c}-0.026^{* *} \\
(-2.14)\end{array}$ \\
\hline CFO & + & $\begin{array}{c}0.131^{* * *} \\
(3.17)\end{array}$ & $\begin{array}{c}0.130^{* * *} \\
(3.20)\end{array}$ & $\begin{array}{c}0.133^{* * *} \\
(3.21)\end{array}$ & $\begin{array}{c}0.133^{* * *} \\
(3.21)\end{array}$ & $\begin{array}{c}0.134^{* * *} \\
(3.23)\end{array}$ \\
\hline LAGNI & $?$ & $\begin{array}{l}-0.005 \\
(-1.56)\end{array}$ & $\begin{array}{l}-0.005 \\
(-1.41)\end{array}$ & $\begin{array}{l}-0.006 \\
(-1.58)\end{array}$ & $\begin{array}{l}-0.006 \\
(-1.57)\end{array}$ & $\begin{array}{l}-0.006 \\
(-1.57)\end{array}$ \\
\hline$A G E$ & - & $\begin{array}{c}-0.001^{* * *} \\
(-3.05)\end{array}$ & $\begin{array}{l}-0.007^{* * *} \\
(-12.69)\end{array}$ & $\begin{array}{c}-0.001^{* * *} \\
(-2.84)\end{array}$ & $\begin{array}{c}-0.001^{* * *} \\
(-2.87)\end{array}$ & $\begin{array}{c}-0.001^{* * *} \\
(-2.79)\end{array}$ \\
\hline VOLRET & + & $\begin{array}{c}0.789^{* * *} \\
(9.00)\end{array}$ & $\begin{array}{c}0.830^{* * *} \\
(9.41)\end{array}$ & $\begin{array}{c}0.778^{* * *} \\
(8.99)\end{array}$ & $\begin{array}{c}0.776^{* * *} \\
(8.97)\end{array}$ & $\begin{array}{c}0.778^{* * *} \\
(8.99)\end{array}$ \\
\hline LINC & + & $\begin{array}{c}0.618^{* * *} \\
(5.04)\end{array}$ & $\begin{array}{c}0.528^{* * *} \\
(4.28)\end{array}$ & $\begin{array}{c}0.600^{* * *} \\
(4.96)\end{array}$ & $\begin{array}{c}0.602^{* * *} \\
(4.97)\end{array}$ & $\begin{array}{c}0.600^{* * *} \\
(4.96)\end{array}$ \\
\hline LIT & + & $\begin{array}{l}0.005 \\
(0.35)\end{array}$ & $\begin{array}{l}0.005 \\
(0.36)\end{array}$ & $\begin{array}{l}0.002 \\
(0.19)\end{array}$ & $\begin{array}{l}0.002 \\
(0.16)\end{array}$ & $\begin{array}{l}0.002 \\
(0.22)\end{array}$ \\
\hline Intercept & & $\begin{array}{c}0.499^{* * * *} \\
(8.02)\end{array}$ & $\begin{array}{l}0.153^{* *} \\
(2.02)\end{array}$ & $\begin{array}{c}0.501^{* * *} \\
(8.29)\end{array}$ & $\begin{array}{c}0.503^{* * *} \\
(8.32)\end{array}$ & $\begin{array}{c}0.500^{* * *} \\
(8.25)\end{array}$ \\
\hline $\begin{array}{l}\text { Year/Industry } \\
\text { Fixed Effect }\end{array}$ & & Included & Included & Included & Included & Included \\
\hline Adjusted $\mathrm{R}^{2}$ & & 0.488 & 0.491 & 0.486 & 0.485 & 0.485 \\
\hline Number of obs. & & 13,571 & 13,877 & 12,305 & 11,879 & 12,119 \\
\hline
\end{tabular}

Second, as suggested by Boubakri et al. [76], because companies are more likely to self-select a political connection based on their specific characteristics, the dummy variable $P C$ may not be exogenous, but endogenous. Political connections may also be determined by several unobserved firm characteristics, thus leading the results to be inconsistent and biased. Therefore, we used instrumental variables estimation and performed our data analysis using near-neighbor observations. At the first-stage regression, we predicted political connections regressing on firm age, firm size, financial 
leverage, market-to-book ratio, and whether the firm is listed overseas. At the second stage, we incorporated the variable of predicted political connections (PC_hat) into Equation (5). Column (2) of Table 5 shows that the sign and significance of the interaction term, FAMOWN ${ }^{*} P C$ hat, remained unchanged, which is the same as the previous result given in Table 3.

Third, we explored how definition matters by comparing differences in accounting conservatism across three alternative definitions of political connections (e.g., chairman, CEO, or board of directors has political connections). To make the test clearer, the benchmark group was the firm-years without political connections. The definitions are listed in Columns (3)-(5) of Table 5 and the findings were generally consistent with the results in Table 3; thus, different types of political connections, such as chairman, CEO, or board of directors having political connections, tended to mitigate the demand for conservative financial reporting in family firms. In summary, our inferences did not change significantly when we deleted the observations owned by government or a political party, controlled for endogeneity, or used an alternative definition of political connections.

\subsubsection{Asymmetric Timeliness of Earnings}

To explore whether family firms tend to recognize bad news more than good news in a timely manner, we used Basu's [3] asymmetric timeliness measure, which regresses earnings on returns and allows the return coefficient to vary with the direction of the return. To test our hypotheses, we followed a previous study [34] and modified Basu [3] as below:

$$
\begin{aligned}
N_{i t} & =\lambda_{0}+\lambda_{1} N E G_{i t}+\lambda_{2} R_{E T} T_{i t}+\lambda_{3} R E T_{i t} * N E G_{i t}+\lambda_{4} F_{A M O W N}+\lambda_{5} N E G_{i t} * F_{i t} \text { AMOWN }_{i t} \\
& +\lambda_{6} \text { RET }_{i t} * F A M O W N_{i t}+\lambda_{7} R E T_{i t} * N E G_{i t} * F A M O W N_{i t}+\lambda_{8} \text { CONTROLS }_{i t} \\
& +\lambda_{9} N E T_{i t} * \text { CONTROLS }_{i t}+\lambda_{10} R E T_{i t} * N E G_{i t} * \text { CONTROLS }_{i t}+\varepsilon_{i t}
\end{aligned}
$$

In Equation (6), the key coefficient of interest is $\lambda_{7}$, which captures the average difference in conservatism between family and nonfamily firms. A positive $\lambda_{7}$ indicates that family firms have more conservative accounting.

Table 6 reveals the results of testing the relationship between family firms and conservative financial reporting. Based on the full sample, Column (1) shows that the coefficient of interaction term, $R E T^{*} N E G^{*} F A M O W N$, was significantly positive (coefficient $=0.064$ ), suggesting that family firms have more incentives to implement conservative financial reporting. To examine the moderating role of political connections, Columns (2) and (3) in Table 6 were estimated separately for non-politically connected firms $(P C=0)$ and politically connected firms $(P C=1)$. As shown by the result for the non-politically connected sample in Column (2), we found a significant coefficient on $R E T^{*} N E G^{*} F A M O W N$ (coefficient $=0.102$ ), which indicates that family firms without political connections still tend to adopt conservative accounting. However, regarding the politically connected sample in Column (3), the coefficients on $R E T^{*} N E G^{*} F A M O W N$ were insignificant. Therefore, the results of Table 6 indicate that accounting conservatism was positively related to family control in firms without political connections, but was unrelated to family firms with political connections. 
Table 6. Family-controlled, political connections, and asymmetric timeliness of earnings.

\begin{tabular}{|c|c|c|c|c|}
\hline & \multirow{4}{*}{ Expected Sign } & \multicolumn{3}{|c|}{ Dependent Variable $=N I$} \\
\hline & & (1) & (2) & (3) \\
\hline & & Full Sample & Subsample: $P C=0$ & Subsample: $P C=1$ \\
\hline & & $\begin{array}{c}\text { Coef. } \\
\text { (t-stat.) }\end{array}$ & $\begin{array}{c}\text { Coef. } \\
\text { (t-stat.) }\end{array}$ & $\begin{array}{c}\text { Coef. } \\
\text { (t-stat.) }\end{array}$ \\
\hline NEG & & $\begin{array}{l}-0.190^{*} \\
(-1.69)\end{array}$ & $\begin{array}{c}-0.248^{* *} \\
(-2.28)\end{array}$ & $\begin{array}{l}-0.140 \\
(-0.75)\end{array}$ \\
\hline RET & & $\begin{array}{l}0.242^{* *} \\
(2.17)\end{array}$ & $\begin{array}{l}0.276^{* *} \\
(2.12)\end{array}$ & $\begin{array}{l}0.212^{* *} \\
(2.07)\end{array}$ \\
\hline$R E T^{*} N E G$ & + & $\begin{array}{c}0.482^{* *} \\
(2.11)\end{array}$ & $\begin{array}{c}0.611^{* *} \\
(2.28)\end{array}$ & $\begin{array}{c}0.369^{* *} \\
(1.99)\end{array}$ \\
\hline FAMOWN & & $\begin{array}{l}0.064^{* *} \\
(2.28)\end{array}$ & $\begin{array}{l}0.078^{* *} \\
(2.45)\end{array}$ & $\begin{array}{l}0.040 \\
(1.08)\end{array}$ \\
\hline NEG ${ }^{*} F A M O W N$ & & $\begin{array}{l}-0.028 \\
(-0.84)\end{array}$ & $\begin{array}{l}-0.042 \\
(-1.13)\end{array}$ & $\begin{array}{l}-0.039 \\
(-0.47)\end{array}$ \\
\hline$R T^{*} F A M O W N$ & & $\begin{array}{l}0.063^{*} \\
(1.69)\end{array}$ & $\begin{array}{l}0.089^{* *} \\
(2.05)\end{array}$ & $\begin{array}{l}-0.006 \\
(-0.10)\end{array}$ \\
\hline$R E T^{*} N E G^{*} F A M O W N$ & + & $\begin{array}{l}0.096^{*} \\
(1.95)\end{array}$ & $\begin{array}{l}0.102^{* *} \\
(2.29)\end{array}$ & $\begin{array}{l}0.053 \\
(0.64)\end{array}$ \\
\hline CONTROLS & & Included & Included & Included \\
\hline NEG ${ }^{*}$ CONTROLS & & Included & Included & Included \\
\hline RET $^{*}$ CONTROLS & & Included & Included & Included \\
\hline$R E T^{*} N E G^{*} P C O W N$ & - & $\begin{array}{l}-0.025 \\
(-1.16)\end{array}$ & $\begin{array}{l}-0.021 \\
(-1.05)\end{array}$ & $\begin{array}{l}-0.014 \\
(-1.55)\end{array}$ \\
\hline$R E T^{*} N E G^{*} O U T O W N$ & - & $\begin{array}{l}-0.394 \\
(-1.44)\end{array}$ & $\begin{array}{l}-0.384 \\
(-1.26)\end{array}$ & $\begin{array}{l}0.059 \\
(0.09)\end{array}$ \\
\hline$R E T^{*} N E G^{*} I N S T$ & + & $\begin{array}{l}-0.436^{* * *} \\
(-2.90)\end{array}$ & $\begin{array}{l}-0.557^{* * *} \\
(-2.95)\end{array}$ & $\begin{array}{l}-0.024 \\
(-0.11)\end{array}$ \\
\hline$R E T^{*} N E G^{*} S I Z E$ & - & $\begin{array}{l}-0.026 \\
(-1.55)\end{array}$ & $\begin{array}{l}-0.036^{*} \\
(-1.80)\end{array}$ & $\begin{array}{l}-0.023 \\
(-0.96)\end{array}$ \\
\hline$R E T^{*} N E G^{*} L E V$ & + & $\begin{array}{l}0.272^{* *} \\
(2.34)\end{array}$ & $\begin{array}{l}0.259 * * \\
(1.92)\end{array}$ & $\begin{array}{l}0.259 \\
(1.35)\end{array}$ \\
\hline$R E T^{*} N E G^{*} M T B$ & - & $\begin{array}{l}-0.003 \\
(-0.52)\end{array}$ & $\begin{array}{l}-0.003 \\
(-0.44)\end{array}$ & $\begin{array}{l}-0.067^{* *} \\
(-2.87)\end{array}$ \\
\hline$R E T^{*} N E G^{*} C F O$ & + & $\begin{array}{l}0.151 \\
(1.17)\end{array}$ & $\begin{array}{l}0.153 \\
(1.14)\end{array}$ & $\begin{array}{l}0.523^{* * *} \\
(2.34)\end{array}$ \\
\hline$R E T^{*} N E G^{*} L A G N I$ & $?$ & $\begin{array}{l}-0.148^{*} \\
(-1.98)\end{array}$ & $\begin{array}{l}-0.149^{*} \\
(-1.76)\end{array}$ & $\begin{array}{l}-0.156 \\
(-1.00)\end{array}$ \\
\hline$R E T^{*} N E G^{*} A G E$ & - & $\begin{array}{l}-0.000 \\
(-0.07)\end{array}$ & $\begin{array}{l}-0.000 \\
(-0.06)\end{array}$ & $\begin{array}{l}-0.003 \\
(-0.89)\end{array}$ \\
\hline$R E T^{*} N E G^{*} V O L R E T$ & + & $\begin{array}{l}0.269 \\
(0.92)\end{array}$ & $\begin{array}{l}0.216 \\
(0.64)\end{array}$ & $\begin{array}{l}0.603 \\
(1.23)\end{array}$ \\
\hline$R E T^{*} N E G^{*} L I N C$ & + & $\begin{array}{l}0.066 \\
(0.12)\end{array}$ & $\begin{array}{l}0.262 \\
(0.44)\end{array}$ & $\begin{array}{l}-1.012 \\
(-0.78)\end{array}$ \\
\hline$R E T^{*} N E G^{*} L I T$ & + & $\begin{array}{c}0.040 \\
(0.132)\end{array}$ & $\begin{array}{c}0.030 \\
(0.091)\end{array}$ & $\begin{array}{l}0.052 \\
(0.89)\end{array}$ \\
\hline Intercept & & $\begin{array}{c}0.166^{* *} \\
(1.98)\end{array}$ & $\begin{array}{l}0.187^{*} \\
(1.90)\end{array}$ & $\begin{array}{l}0.013 \\
(1.08)\end{array}$ \\
\hline $\begin{array}{c}\text { Year/Industry Fixed } \\
\text { Effect }\end{array}$ & & Included & Included & Included \\
\hline Adjusted $\mathrm{R}^{2}$ & & 0.223 & 0.223 & 0.287 \\
\hline Number of obs. & & 13,877 & 11,199 & 2678 \\
\hline
\end{tabular}

$\mathrm{NI}$ is net income before extraordinary items scaled by lagged market value of equity. RET is buy and hold return over the fiscal year. NEG is an indicator that equals one if $R E T$ is negative and zero otherwise. See Table 1 for definitions of all variables. * ,**, and ${ }^{* * *}$ denote significance at the $10 \%, 5 \%$, and $1 \%$ levels, respectively (two-tailed test). Robust t-statistics (clustered standard errors by firm) are shown in parentheses. 


\section{Conclusions}

This study examined how political connections affect conservative financial reporting, which is how the political connections affect the timely recognition of economic loss and gain for family firms. This study analyzed the role of conservative financial reporting and contract decisions of family firms. Unlike prior research that investigated the effect of corporate governance in earnings conservatism [34,77], we not only provided the evidence on the impact of specific family firm features on accounting conservatism, but also revealed the significant moderating effect of political connections as an important determinant of accounting conservatism. We expanded the research field on the relation between the political economy and the quality of accounting information, which mainly focuses on a setting in which agency conflict stems from family members and other stakeholders. It indicated that the government and capital market regulatory authorities easily neglect the supervision and regulation of politically connected firms and weaken the punishment upon their improper behaviors of earnings disclosure. It supports that politically connected family firms are less likely to release bad news in a timely manner as compared with good news.

Further analysis suggested that family firms with founder or descendent CEOs who have political connections are also less likely to engage in conservative financial reporting. After checking the robustness of these findings, we controlled for sample-selected problems and endogeneity, considered an alternative definition of political connections, and used another accounting conservatism measurement; however, the results were still robust to all of these sensitivity examinations. Therefore, this study contributes to the academic literature on how political connections affect family owners' reporting incentives. Policy makers may consider political connections as an essential factor with respect to establishing governance practice for family firms.

A potential limitation of this study is the measure of political connection, because our measure of political connections only captured a shelter of business risk and identified for politicians pursuing personal benefits. There still exists another proxy for a shelter of business risk and future research can further explore the shelter of business risk. In fact, this study still provides several avenues for future research. It would be interesting for future studies to compare the economic consequences of the family firms inherited by the founders' descendants and those managed by outsiders. While few family firms have currently passed their ownership and control to outsiders, this new issue can create a better research field of how the family succession process serves as a specific factor in accounting quality and information transparency of family firms.

Author Contributions: Four co-authors together contributed to the completion of this article. H.-Y.C. acted as corresponding author on their behalf throughout the revision and submission process. T.-C.W. contributed to reviewing the manuscript and revising the results and conclusion; G.-Z.C. contributed to reviewing and revising the literature, results, and conclusion; S.-P.C. contributed to the research design, investigation, and data analysis.

Funding: This research received no external funding.

Acknowledgments: We acknowledge the comments of participants at the 2016 American Accounting Association Annual Meeting and 2016 Academic Conference of Accounting. We also appreciate the comments of the workshop participants at National Chung Hsing University, National Changhua University of Education, Feng Chia University, and Yuan Ze University for helpful comments and suggestions. Professor Chi acknowledges the financial support of the Ministry of Science Technology in Taiwan (MOST 103-2628-H-005-001-MY3).

Conflicts of Interest: The authors declare no conflict of interest.

\section{References}

1. Anderson, R.C.; Reeb, D.M. Founding-family ownership and firm performance: Evidence from the S\&P 500. J. Financ. 2003, 58, 1301-1327.

2. Villalonga, B.; Amit, R. How do family ownership control and management affect firm value? J. Financ. Econ. 2006, 80, 385-417. [CrossRef]

3. Basu, S.; Hwang, L.S.; Mitsudome, T.; Weintrop, J. Corporate governance top executive compensation and firm performance in Japan. Pac.-Basin Financ. J. 2007, 15, 56-79. [CrossRef] 
4. Watts, R.L. Conservatism in accounting part I: Explanations and implications. Account. Horiz. 2003, 17, 207-221. [CrossRef]

5. Ball, R.; Shivakumar, L. Earnings quality in UK private firms: Comparative loss recognition timeliness. J. Account. Econ. 2005, 39, 83-128. [CrossRef]

6. Wang, D. Founding family ownership and earnings quality. J. Account. Res. 2006, 44, 619-656. [CrossRef]

7. Ali, A.; Chen, T.Y.; Radhakrishnan, S. Corporate disclosures by family firms. J. Account. Econ. 2007, 44, 238-286. [CrossRef]

8. Chen, S.; Chen, X.; Cheng, Q. Do family firms provide more or less voluntary disclosure? J. Account. Res. 2008, 46, 499-536. [CrossRef]

9. Chen, S.; Chen, X.; Cheng, Q.; Shevlin, T. Are family firms more tax aggressive than non-family firms? J. Financ. Econ. 2010, 95, 41-61. [CrossRef]

10. Beaver, W.H.; Ryan, S.G. Conditional and unconditional conservatism: Concepts and modeling. Rev. Account. Stud. 2005, 10, 269-309. [CrossRef]

11. Chen, S.; Chen, X.; Cheng, Q. Conservatism and equity ownership of the founding family. Eur. Account. Rev. 2014, 23, 403-430. [CrossRef]

12. Fan, J.P.; Wong, T.J.; Zhang, T. Politically connected CEOs corporate governance and Post-IPO performance of China's newly partially privatized firms. J. Financ. Econ. 2007, 84, 330-357. [CrossRef]

13. Chen, C.J.; Li, Z.; Su, X.; Sun, Z. Rent-seeking incentives corporate political connections and the control structure of private firms: Chinese evidence. J. Corp. Financ. 2011, 17, 229-243. [CrossRef]

14. Li, H.; Meng, L.; Wang, Q.; Zhou, L.A. Political connections financing and firm performance: Evidence from Chinese private firms. J. Dev. Econ. 2008, 87, 283-299. [CrossRef]

15. Khwaja, A.I.; Mian, A. Do lenders favor politically connected firms? Rent provision in an emerging financial market. Q. J. Econ. 2005, 120, 1371-1411. [CrossRef]

16. Dinç, I.S. Politicians and banks: Political influences on government-owned banks in emerging markets. J. Financ. Econ. 2005, 77, 453-479. [CrossRef]

17. Faccio, M.; Masulis, R.W.; McConnell, J. Political connections and corporate bailouts. J. Financ. 2006, 61, 2597-2635. [CrossRef]

18. Chaney, P.K.; Faccio, M.; Parsley, D. The quality of accounting information in politically connected firms. J. Account. Econ. 2011, 51, 58-76. [CrossRef]

19. Piotroski, J.D.; Wong, T.J.; Zhang, T. Political incentives to suppress negative information: Evidence from Chinese listed firms. J. Account. Res. 2015, 53, 405-459. [CrossRef]

20. Fan, J.P.; Wong, T.J. Do external auditors perform a corporate governance role in emerging markets? Evidence from East Asia. J. Account. Res. 2005, 43, 35-72. [CrossRef]

21. Claessens, S.; Djankov, S.; Lang, L.H. The separation of ownership and control in East Asian corporations. J. Financ. Econ. 2000, 58, 81-112. [CrossRef]

22. Fan, J.P.; Wong, T.J. Corporate ownership structure and the informativeness of accounting earnings in East Asia. J. Account. Econ. 2002, 33, 401-425. [CrossRef]

23. Yeh, Y.H.; Lee, T.S.; Woidtke, T. Family control and corporate governance: Evidence from Taiwan. Int. Rev. Financ. 2001, 2, 21-48. [CrossRef]

24. Sue, S.-H.; Chin, C.-L.; Nien, K.T. How Agency Problem and Reputation for Integrity Influence Family Firms' Conference Call Disclosures? J. Manag. 2014, 31, 217-243.

25. Johnson, S.; Mitton, T. Cronyism and capital controls: Evidence from Malaysia. J. Financ. Econ. 2003, 67, 351-382. [CrossRef]

26. Leuz, C.; Oberholzer-Gee, F. Political relationships global financing and corporate transparency: Evidence from Indonesia. J. Financ. Econ. 2006, 81, 411-439. [CrossRef]

27. Bliss, M.A.; Gul, F.A. Political connection and cost of debt: Some Malaysian evidence. J. Bank. Financ. 2012, 36, 1520-1527. [CrossRef]

28. Fraser, D.R.; Zhang, H.; Derashid, C. Capital structure and political patronage: The case of Malaysia. J. Bank. Financ. 2006, 30, 1291-1308. [CrossRef]

29. Ahmed, A.S.; Billings, B.K.; Morton, R.M.; Stanford-Harris, M. The role of accounting conservatism in mitigating bondholder-shareholder conflicts over dividend policy and in reducing debt costs. Account. Rev. 2002, 77, 867-890. [CrossRef] 
30. Watts, R.L. Conservatism in accounting part II: Evidence and research opportunities. Account. Horiz. 2003, 17, 287-301. [CrossRef]

31. Nikolaev, V.V. Debt covenants and accounting conservatism. J. Account. Res. 2010, 48, 51-89. [CrossRef]

32. Zhang, J. The contracting benefits of accounting conservatism to lenders and borrowers. J. Account. Econ. 2008, 45, 27-54. [CrossRef]

33. Ahmed, A.S.; Duellman, S. Evidence on the role of accounting conservatism in monitoring managers' investment decisions. Account. Financ. 2011, 51, 609-633. [CrossRef]

34. LaFond, R.; Watts, R.L. The information role of conservatism. Account. Rev. 2008, 83, 447-478. [CrossRef]

35. Shuto, A.; Takada, T. Managerial ownership and accounting conservatism in Japan: A test of management entrenchment effect. J. Bus. Financ. Account. 2010, 37, 815-840. [CrossRef]

36. Baker, T.; Collins, D.; Reitenga, A. Stock option compensation and earnings management incentives. J. Account. Audit. Financ. 2003, 18, 557-582. [CrossRef]

37. Bergstresser, D.; Philippon, T. CEO incentives and earnings management. J. Financ. Econ. 2006, 80, 511-529. [CrossRef]

38. Smith, C.W.; Watts, R.L. The investment opportunity set and corporate financing, dividend, and compensation policies. J. Financ. Econ. 1992, 32, 263-292. [CrossRef]

39. Brown, W.D., Jr.; He, H.; Teitel, K. Conditional conservatism and the value relevance of accounting earnings: An international study. Eur. Account. Rev. 2006, 15, 605-626. [CrossRef]

40. Chen, Q.; Hemmer, T.; Zhang, Y. On the relation between conservatism in accounting standards and incentives for earnings management. J. Account. Res. 2007, 45, 541-565. [CrossRef]

41. Anderson, R.C.; Mansi, S.A.; Reeb, D.M. Founding family ownership and the agency cost of debt. J. Financ. Econ. 2003, 68, 263-285. [CrossRef]

42. Anderson, R.C.; Duru, A.; Reeb, D.M. Investment policy in family controlled firms. J. Bank. Financ. 2012, 36, 1744-1758. [CrossRef]

43. Demsetz, H.; Lehn, K. The structure of corporate ownership: Causes and consequences. J. Political Econ. 1985, 93, 1155-1177. [CrossRef]

44. Shleifer, A.; Vishny, R.W. A survey of corporate governance. J. Financ. 1997, 52, 737-783. [CrossRef]

45. Shleifer, A.; Vishny, R.W. Large shareholders and corporate control. J. Political Econ. 1986, 94, 461-488. [CrossRef]

46. Edmans, A.; Manso, G. Governance through trading and intervention: A theory of multiple blockholders. Rev. Financ. Stud. 2011, 24, 2395-2428. [CrossRef]

47. Chen, C.J.; Ding, Y.; Kim, C.F. High-level politically connected firms corruption and analyst forecast accuracy around the world. J. Int. Bus. Stud. 2010, 41, 1505-1524. [CrossRef]

48. Basu, S. The conservatism principle and the asymmetric timeliness of earnings. J. Account. Econ. 1997, 24, 3-37. [CrossRef]

49. Ball, R.; Kothari, S.P.; Robin, A. The effect of international institutional factors on properties of accounting earnings. J. Account. Econ. 2000, 29, 1-51. [CrossRef]

50. Casson, M. The economics of the family firm. Scand. Econ. Hist. Rev. 1999, 47, 10-23. [CrossRef]

51. Wiseman, R.M.; Gomez-Mejia, L.R. A behavioral agency model of managerial risk taking. Acad. Manag. Rev. 1998, 23, 133-153. [CrossRef]

52. Chatterjee, S.; Lubatkin, M.H.; Lyon, E.M.; Schulze, W.S. Toward a strategic theory of risk premium: Moving beyond CAPM. Acad. Manag. Rev. 1999, 24, 556-567. [CrossRef]

53. Holthausen, R.W.; Watts, R.L. The relevance of the value-relevance literature for financial accounting standard setting. J. Account. Econ. 2001, 31, 3-75. [CrossRef]

54. Blunck, R. Does Conservative Accounting Reduce Litigation Costs? Working Paper; University of Iowa: Iowa City, IA, USA, 2009.

55. Faccio, M. Politically connected firms. Am. Econ. Rev. 2006, 96, 369-386. [CrossRef]

56. Ferguson, T.; Voth, H. Betting on Hitler-The Value of Political Connections in Nazi Germany. Q. J. Econ. 2008, 123, 101-137. [CrossRef]

57. Drope, J.M.; Hansen, W.L. Purchasing protection? The effect of political spending on US trade policy. Political Res. Q. 2004, 57, 27-37. [CrossRef]

58. Goldman, E.; Rocholl, J.; So, J. Do politically connected boards affect firm value? Rev. Financ. Stud. 2009, 22, 2331-2360. [CrossRef] 
59. Duchin, R.; Sosyura, D. The politics of government investment. J. Financ. Econ. 2012, 106, 24-48. [CrossRef]

60. Faccio, M. Differences between politically connected and nonconnected firms: A cross-country analysis. Financ. Manag. 2010, 39, 905-928. [CrossRef]

61. Shleifer, A.; Vishny, R.W. Politicians and firms. Q. J. Econ. 1994, 109, 995-1025. [CrossRef]

62. Faccio, M.; Lang, L.H. The ultimate ownership of Western European corporations. J. Financ. Econ. 2002, 65, 365-395. [CrossRef]

63. Shleifer, A.; Vishny, R.W. The Grabbing Hand. Government Pathologies and Their Cures. Q. J. Econ. 2002, $117,1-37$.

64. Rosa, J.J.; Perard, E. When to privatize? When to nationalize? A competition for ownership approach. Kyklos 2010, 63, 110-132. [CrossRef]

65. Gul, F.A. Auditors' response to political connections and cronyism in Malaysia. J. Account. Res. 2006, 44, 931-963. [CrossRef]

66. Khan, M.; Watts, R.L. Estimation and empirical properties of a firm-year measure of accounting conservatism. J. Account. Econ. 2009, 48, 132-150. [CrossRef]

67. Chi, W.C.; Wang, C.C. Accounting conservatism in a setting of Information Asymmetry between majority and minority shareholders. Int. J. Account. 2010, 45, 465-489. [CrossRef]

68. La Porta, R.; Lopez-de-Silanes, F.; Shleifer, A. Corporate ownership around the world. J. Financ. 1999, 54, 471-517. [CrossRef]

69. Marzuki, M.M.; Wahab, E.A.A. Institutional factors and conditional conservatism in Malaysia: Does international financial reporting standards convergence matter? J. Contemp. Account. Econ. 2016, 12, 191-209. [CrossRef]

70. Bona-Sanchez, C.; Perez-Aleman, J.; Santana-Mart, D.J. Politically connected firms and earnings informativeness in the controlling versus minority shareholders context: European evidence. Corp. Gov. Int. Rev. 2014, 22, 330-346. [CrossRef]

71. Ahmed, A.S.; Duellman, S. Accounting conservatism and board of director characteristics: An empirical analysis. J. Account. Econ. 2007, 43, 411-437. [CrossRef]

72. Givoly, D.; Hayn, C.K.; Natarajan, A. Measuring reporting conservatism. Account. Rev. 2007, 82, 65-106. [CrossRef]

73. Ramalingegowda, S.; Yu, Y. Institutional ownership and conservatism. J. Account. Econ. 2012, 53, 98-114. [CrossRef]

74. Field, L.; Lowry, M.; Shu, S. Does disclosure deter or trigger litigation? J. Account. Econ. 2005, 39, 487-507. [CrossRef]

75. Chandra, U. Income conservatism in the US technology sector. Account. Horiz. 2011, 25, 285-314. [CrossRef]

76. Boubakri, N.; Cosset, J.C.; Saffar, W. The impact of political connections on firms' operating performance and financing decisions. J. Financ. Res. 2012, 35, 397-423. [CrossRef]

77. Bona-Sánchez, C.; Pérez-Alemán, J.; Santana-Martín, D.J. Ultimate ownership and earnings conservatism. Eur. Account. Rev. 2011, 20, 57-80. [CrossRef]

(C) 2019 by the authors. Licensee MDPI, Basel, Switzerland. This article is an open access article distributed under the terms and conditions of the Creative Commons Attribution (CC BY) license (http://creativecommons.org/licenses/by/4.0/). 